\title{
Features of an Experimental Station at an International Agricultural Research Center that Enhance Regional Impact
}

\author{
John Ryan ${ }^{1}$, Colin Norwood ${ }^{1} \&$ Juergen Diekmann ${ }^{1}$ \\ ${ }^{1}$ International Center for Agricultural Research in the Dry Areas (ICARDA), Aleppo, Syria \\ Correspondence: John Ryan, International Center for Agricultural Research in the Dry Areas (ICARDA), Aleppo, \\ Syria. Tel: 963-21-2691-2741. Email: j.ryan@cgiar.org
}

Received: December 15, 2011 Accepted: April 12, 2012 Online Published: July 16, 2012

doi:10.5539/sar.v1n2p88

URL: http://dx.doi.org/10.5539/sar.v1n2p88

\begin{abstract}
Adequately equipped field stations are essential for any institution involved with applied agricultural research. The field station is particularly crucial to the functioning of the network of global international research centers. The International Center for Agricultural Research in the Dry Areas addresses issues mainly related to dryland cropping system of the West Asia and North Africa region. It extends its effectiveness in northern Syria through a range of sub-stations and on-farm sites across the rainfall transect $(150-600 \mathrm{~mm})$. This article describes the environment and management of the Center that backstops its applied and adaptive research. Particular strengths of the station are highlighted. Unique features of the station that further the technology generation and transfer are described. While some aspects of international research station management are generic, there are considerations described that are specific to an evolving dryland research center in a rapidly changing region.
\end{abstract}

Keywords: field experimentation, Middle Eastern agriculture, dryland cropping, technology transfer

\section{Introduction}

Despite the technological achievement in agriculture in the past century, which brought enormous benefits to mankind, the challenges we now face are daunting. These challenges hinge on population growth rates and global resources. World population increased fourfold in the 20th Century, together with a similar increase in economic activity per person (Sacks, 2004). With population scheduled to increase by $50 \%$ in the next four to five decades, food output will have to be doubled. Worldwide economic activity is projected to increase five-fold in that period, bringing unprecedented stress on the environment, coincident with similar increases in energy consumption and manufacturing (World Resources Institute, 2000).

Following a penetrating analysis of the origins and progress of agriculture in the past 10,000 years, Miller (2008) argued that the future of agriculture and mankind are molded by science; while some elements of production will change, others will remain, but the ecological foundation of the human-nature-agriculture interconnectedness should be sustained. While Kirschenmann (2007) questioned the principles underpinning industrial agriculture of the past, he opined that the future should be based on a more diverse and complex system of food and fiber production.

Against this global imperative to produce more food, and to do it is a sustainable manner without determent to the earth's natural resources (e.g., soil, water, biodiversity), the research challenges for agricultural scientists have never been greater, especially in lesser developed countries that account for most of the world's population growth (Godfray et al., 2010). Investment in agricultural research generally delivers high rates of return in terms of increasing productivity, improving nutrition, and reducing poverty. For example, for 700 World Bank projects in developing countries, the return was $43 \%$ (World Development Report, 2008). For poorest people, growth in agriculture was four times more effective in reducing poverty than growth outside the sector. In short, greater investment is vital to ensure agricultural development, especially in funding international research institutions designed to promote development.

\section{The International Agricultural Research Centers}

In the context of global developments, the Consultative Group on International Agricultural Research (CGIAR) was founded as a global network of agricultural research and development centers to boost food output, improve livelihoods, enhance quality of life and underpin the stability of societies in the developing world (Deane et al., 
2010). Pivotal to the success of such centers for effective technology generation and transfer are the Centers' field experiment stations. From the establishment of the world's oldest agricultural experiment station at Rothamsted in England in the mid $19^{\text {th }}$ Century, field stations have contributed to the solution of problems of immediate concern to agriculture, especially in the area of agronomy. Indeed, such field experimentation has even contributed to the solution of problems not apparent at the time of establishment.

While most experiment stations in developed countries address national or state issues, the challenge to CGIAR centers was even greater as their experiment stations had to accommodate both site-specific and regional issues in their mandate countries. In addition to unique biophysical constraints to agricultural development in the developing countries, there are also specific socio-cultural conditions. Success in development requires an understanding of small-scale farmers (Rhoades, 1984), which predominate in lesser-developed countries, and technologies appropriate for such farmers (Brams, 1980).

Consequently, most of the major CGIAR centers, such as the International Rice Research Institute (IRRI) in the Philippines, the World Wheat and Maize Center (CIMMYT) in Mexico, and the International Institute of Tropical Agriculture (IITA) in Nigeria, were built around a major station or campus. A common feature of such centers was the establishment of sub-stations in the mandate region in order to make the institute's research of relevance to broader agro-ecological zones. While much of the applied research emanating from CGIAR stations has been extensively published, little has been written about the role and function of the stations themselves.

\section{The International Center for Agricultural Research in the Dry Areas}

The International Center for Agricultural Research in the Dry Areas (ICARDA) was established in 1977 in Aleppo, Syria primarily to address the problems of dryland rainfed cropping in the West Asia and North Africa (WANA)._Despite the antiquity of the region in terms of agriculture and civilization (Harlan, 1992), the region is still a food-deficit one which is faced with many biophysical and socioeconomic constraints (Khuri et al., 2011) The Center shares common features with other international centers with respect to experimental stations. The unique circumstances surrounding the acquisition of land to form the main 950-ha station at Tel Hadya, $30 \mathrm{~km}$ south of Aleppo, were described by Nour (2002) along with the subsequent evolution of the Center. The Center's headquarters and main field station at Tel Hadya has continued to develop in the process of serving the scientific mission of ICARDA. In this article, we have sought to examine, through the prism of ICARDA, the role of a CGIAR experiment station, and its sub-stations, in relation to potential effectiveness for achieving relevance and impact for the Center's mandate region or countries. Such an experimental station is all the more important as it has to have a technology transfer function in a region where formal extension services are weak by western standards (Chaudhry \& Ryan, 1984; Abi-Ghanem et al., 2009) and where the private section is also poorly developed. In a recent assessment of an international development Project in Morocco in the WANA region (Ryan et al., 2007), the absence of a central main station was seen as a drawback to the effectiveness of the Dryland Applied Research Center that was created by the Project.

\section{Experiment Station Conditions: Potential and Drawbacks}

Any research station, regardless of size, represents a site-specific area of land that has inherent limitations in relation to the extent that it is representative of the region to which it wishes to generalize its research findings. The most obvious requirements are that a station be representative of soil type, and, especially for a dryland center, environmental factors such as rainfall and temperature (Kassam, 1981). Similarly, such primary research stations should reflect the prevailing cropping systems practiced and/or "best farming practices". Consequently, brief mention is made of these features of an experiment station.

\subsection{Soils and Land Management}

Historically, research stations in the WANA region tended to be sited on the most productive soils. In some situations, soil representativeness is not the primary reason for establishment; often it is for pragmatic reasons such as government acquisition of former colonial estates, as in the case of Morocco (Ryan et al., 1990). In the case of the land appropriated for the Tel Hadya station, a consideration was that it was zone of the richest land in the area, being largely representative of deep soils, with only a small part of the station representing the more widespread shallow soils (Illiawi, 1985). As soils on any landscape are inherently spatially variable, the Station's soils vary widely, especially in terms of depth. However, it was not until 1981 that some preliminary classification of the soil at Tel Hadya and its sub-stations was made along with observations on fertility. Indeed, nutrient variability is a feature of such experimental stations that is not easy to overcome (Ryan et al., 2012a), but is something that has to be considered in designing field trials.

Out of the 950-ha total area of Tel Hadya station about 780 ha are suitable for cropping, with only 450 to 480 ha 
being deemed suitable by scientists for small-plot research based on adequate depth and being relatively level. The remainder is hilly with shallow soils, with common rock outcrops, and is suitable for rangeland grazing and forage shrubs. While rangelands are rarely if ever fertilized, especially as they are usually in the public or common domain, the Tel Hadya rangeland area involved a long-term trial that demonstrated the positive influence of phosphorus fertilization on vegetative growth, botanical composition, and animal output (Osman et al., 1991). The non-cropped area has recently been reduced as a result of extensive land reclamation involving extensive rock removal to provide additional land suitable for cultivation; the latter process has also served as a demonstration of the feasibility of such reclamation in areas of Syria where stony soils predominate.

Recognizing the need to describe the soil features of the station as a guide to more effectively use the land for experimentation led to a soil survey of the station (Ryan et al., 1997) in which the main soils were scientifically classified, i.e., according to Soil Taxonomy (1975). Though not detailed, the report indicated variation in soil properties that influenced cropping, particularly with respect to water use. As scientific classification of soil is essential to publication of field research from the station, the survey was a major boost to adding value to published output from the Center. Ideally, any station, at its establishment, should be surveyed in detail, with depiction of the spatial variability of the soil types and details of the various physical and chemical properties that influence valid cropping experimentation. Descriptions of the various soil profiles are vital to illustrate the importance of what lies beneath the surface with respect to the station's productivity. Soil depth is of particular relevance as it controls the soil's capacity to store water and influence rooting volume. Some stations have permanent profiles exposed and labeled as an educational tool for both scientists and visitors.

\subsection{Environmental Conditions}

While most of Syria is desert or scrubland, a significant portion has sufficient rainfall for rainfed or dryland agriculture (Figure 1).The transect across rainfall zones in Syria represent extremes at either side of the normal rainfed cropping range $(150-600 \mathrm{~mm})$. With rainfall ranging from less than $100 \mathrm{~mm}$ in central Syria to $1200 \mathrm{~mm}$ in the mountains to the west, rainfed cropping is mainly practiced in the 200 to $500 \mathrm{~mm}$ annual rainfall zone. Located between the $300 \mathrm{~mm}$ and $400 \mathrm{~mm}$ isohyets, Tel Hadya (about $350 \mathrm{~mm}$ ) represents only a segment of the rainfall range that dictates dryland agriculture in Syria, with rainfall being more reliable and droughts less frequent than in areas with less than $300 \mathrm{~mm}$.

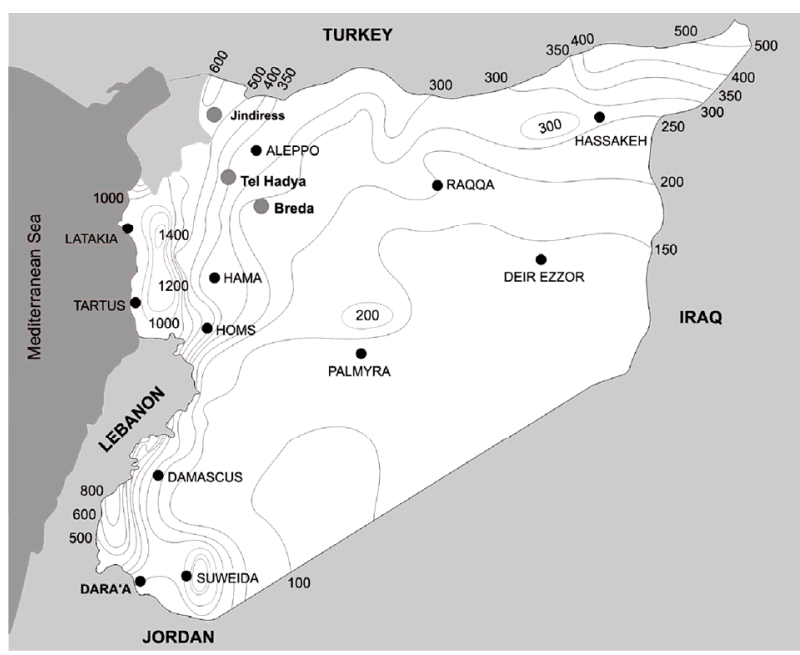

Figure 1. Isohyets indicating rainfall patterns in Syria (Note transect from Jindiress, Tel Hadya, and Breda in the northwest representing a range of rainfall in the dryland agriculture of the WANA region)

ICARDA has compensated for the site-specific main station by having one relatively permanent field station in the drier areas at Breda $(280 \mathrm{~mm})$. For about two decades after establishment in 1977, ICARDA maintained other sites in even drier areas (Boueider, Maragha, Khanasser, Gherife) and one on-farm site in the wetter zone at Jindiress $(480 \mathrm{~mm})$. In addition to rainfall, temperature is a significant factor for field experimentation. Thus, in conjunction with the Lebanese Agricultural Research Institute, Tel Hadya has access to two stations (Terbol, Kfardane) in Lebanon's Bekaa Valley, where the elevation is higher (890-1075 masl), and winter temperatures lower $\left(-5^{\circ} \mathrm{C}\right)$, including frequent snow and frost. 


\subsection{Agro-ecosystems and Crops}

The variation in rainfall in Syria dictates a range of agro-ecological zones (Ryan et al., 2006). These, in fact, broadly reflect the range of conditions that, to varying degrees, exist in many countries of WANA (Figure 2). In the drier extreme $(<100 \mathrm{~mm})$ deserts dominate with irrigation where surface water is available, e.g., Euphrates River. This gives way to native pastures and steppeland ("badia") between 100-200 mm, then barley (Hordeum sativum) in the relatively drier end $(200-300 \mathrm{~mm})$ of the rainfed zone followed largely by bread wheat (Triticum aestivum) and durum wheat (T. durum var turgidum) in the $300-500 \mathrm{~mm}$ range. Livestock, mainly sheep (Ovis aries) and goats (Capra hircus), are integrated with both barley and wheat production systems (Cooper et al., 1987). The most common non-cereal crops are lentil (Lens culinaris), which tends to be associated with drier barley-growing areas, and chickpea (Cicer arietinum) and faba bean (Vicia faba) and oil seed crops such as safflower (Carthamus tinctorious) are common in wheat-growing areas.

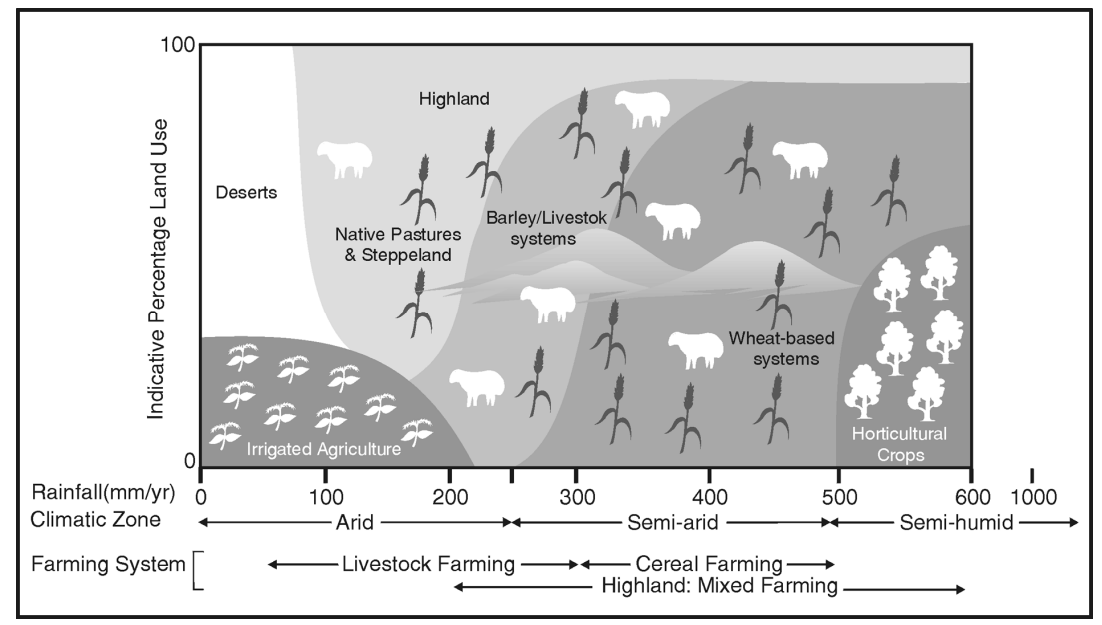

Figure 2. Schematic representation of the farming systems across the rainfall transect in the West Asia-North Africa Region

While agriculture in the Middle East region has had a traditional, low-input character for centuries, indeed millennia, much change has occurred in the past three decades. In addition to increased mechanization and chemical inputs, the most significant development has been increasing irrigation from groundwater in previously rainfed areas, along with crop diversification and decreased fallow with corresponding increases in cereal mono-cropping. With irrigation intensification and limited groundwater recharge, an unplanned function of the station was monitoring of annual changes in groundwater depth. In essence, the challenge to the Tel Hadya experiment station is to maintain scientific relevance to the changing conditions across the entire dryland zone in northern Syria.

\subsection{On-Station: Appropriate Uses}

An experiment station such as Tel Hadya has many inherent advantages for the conduct of applied research as headquarter buildings are all on-site. These include administrative offices, lecture and seminar rooms, research laboratories (biotechnology, entomology, plant pathology, food technology, animal production and health, agronomy and soils, and Farm support facilities such as greenhouses, grain storage and handling buildings, greenhouse complexes, vehicle workshop, and bio-remediated lagoon for chemical wastes. But the real strength of the Center is its land area. Thus, much of the cultivable land area of the Station is devoted to cereal, forage, and legume breeding trials; tillage research, including conservation tillage; weed control experiments and agronomic practices; and supplemental irrigation trials. While many of these trials can be conducted at sub-stations or on-farm, given the appropriate conditions, one area where the station has a comparative advantage is in the area of long-term cropping systems trials, i.e., rotations (Ryan et al., 2008a). While a large area of the Station is normally devoted to cereal and legume variety trials, such trials are now being promoted to a large extent in sub-stations and on farmers' fields given the commonly observed genetic by environment interactions that influence variety adoption by farmers. 


\subsubsection{Rotation Trials}

Crop rotations, involving cereals grown in sequence with fallow or legumes, have been practiced from time immemorial in the Mediterranean region to maintain soil fertility and serve as a strategy against drought. Long-term agronomic trials, invariably featuring crop sequences or rotations, have a long history and have contributed immensely to the advancement of knowledge in the area of crops, agronomy, and soils (Karlen et al., 1994). The rationale for the establishment of several long-term trials at Tel Hadya (with a few smaller trials at the Breda sub-station) was manifold (Ryan et al., 2008a): developing cropping alternatives to cereal monoculture with the decline of fallow; assessing possible developments in managing cereal residues; considering fertilization guidelines beyond the normal one-season crop; examining the gradual change in soil organic matter and other soil quality indicators under different cropping systems with time; quantifying the relatively new concept of fertility buildup; comparing the potential of conservation tillage with conventional tillage; evaluating grazing management strategies with vetch (Vicia sativa) and medic (Medicago spp).

Much published work has emanated from these trials, especially dealing with wheat (Ryan et al., 2010) and barley (Pala et al., 2008), and various aspects of nitrogen (Ryan et al., 2009), thus sharing information of value to the region's farmers and contributing to our understanding of dryland cropping systems. Nevertheless, some shortcomings in the conduct of such cropping systems trials became apparent: e.g., the need for complete baseline soil characterization prior to the experiment, scrutiny of trial treatments and design (Keatinge and Sommel, 1993); the need for planning of such trials for definite number of years, rather than periodic extension based on available funding; and the desirability of considering soil chemical and biological changes, including disease organism, in addition to crop yields.

Given the long-term nature of such cropping system trials, the experimented station is the only realistic site for such trials. As desirable as it is to conduct such trials on-farm, conditions such as small holdings, and need for security and legally building agreements effectively preclude on-farm trials. Recognizing the inherent constraints in conducting long-term cropping system trials within the context of the Middle East region, Jones (2000) suggested an alternative hybrid concept of participatory trials.

\subsubsection{Weather Data and Environmental Monitoring}

An essential feature of any agricultural experiment station is a weather station. As variables such as rainfall, ambient temperatures, Class A Pan evaporation, relative humidity, and wind speed are all crucial factors affecting crop growth and physiology, such measurements are recorded daily at Tel Hadya and other sites. Such measurements are less reliable and secure off-station, where only rainfall measurements are taken. The use of portable electronic weather station in the future may be more desirable. Similarly, given the proximity of the field plots to the laboratory complex, routine measurements of soil moisture are facilitated with the neutron robe, as well as time wise soil temperature using a temperature gauge. Weather data from such a station are vital to modeling of crop growth and will become increasingly important given the likelihood of drier and hotter conditions in the Mediterranean region with probable climate change.

\subsubsection{Fertility and Crop Response Trials}

In contrast to long-term rotation trials, fertilizer-crop response trials are generally unsuitable to experiment station and more appropriate to on-farm research. Experiment stations have multi-purpose uses, including crop variety trials. In such cases where nutrients are not a variable and are added to eliminate the possibility of deficiency in such trials, a gradual buildup of available nutrients occurs, especially with phosphorus (Ryan et al., 2008b). Fortunately, farmers' fields are likely to be lower in nitrogen and phosphorus and therefore more appropriate as illustrated by the many on-farm trials conducted by ICARDA with the Syrian national program (Pala et al., 1996). However, some fertility studies that demand rigorous control and regular monitoring such as within-season nutrient dynamics or nutrient losses are also appropriate for experiment station study (Abdel Monem et al., 2010). Thus, on-station trials may complement simpler response trials on-farm.

\subsection{Management of the Experimental Station}

The task of planning the use of a large experimental station that serves a wide range of biophysical scientists dealing with crops, soil management, water, greenhouses and animal management is a difficult one. Similarly, management of the day-to-day operations of a main station such as Tel Hadya requires expertise in managing the large staff of both skilled and temporary workers, flexibility and responsiveness to change. While the proportion of land or Station facilities is planned in advance with the Center's scientific programs, there are unique features related to the station's management that are highlighted. 


\subsubsection{Field History}

As the planned use of any area of the station, or specific plots, are influenced by previous uses of such areas, a detailed history of each field for each year is essential. The station is laid out in sections (A, B, C and D) and permanent fields within theses sections with a network of permanent graveled roads. Despite the fact that farmers in the region have small and irregular fields, the station has of necessity to have fields of reasonable size to accommodate the largest experiments. Thus, a standard size of $200 \mathrm{~m} \times 300 \mathrm{~m}$ (or $400 \mathrm{~m}$ ) is aimed for. Accurate details of the use (and various treatments applied) of each field is recorded, either in a book or electronically. Keeping and analyzing farm production records are essential to the efficient management of the station but also to allow scientist to make informed decisions regarding their research results.

In addition to such records, a map is produced each year which is color-coded and which shows the use allocated to each field, i.e., crops, and the responsible scientific program (Figure 3). These maps are made available to all scientists involved in field experiment as well as being used for distribution to trainees and visitors. Given the variety of trials conducted at the station, with plots of varying size, a key concern is uniformity of any area designed for a particular experiment.

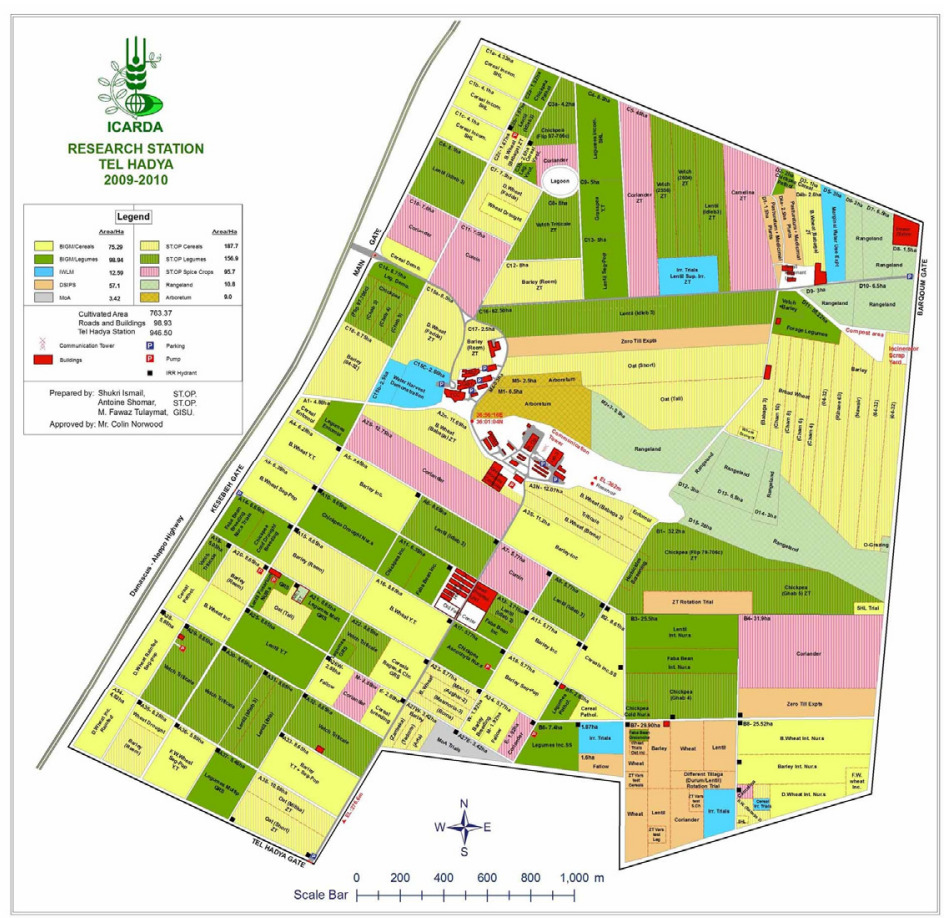

Figure 3. Land Use Map of Tel Hadya Station, 2009/2010

\subsubsection{Homogenization and Rotations}

Field trials require homogenous areas for any one trial so that small plots experiments can be successfully used to compare effects such as varieties and agronomic practices with a high degree of confidence that such differences are real and due to treatment variables and not due to soil differences, inherent or due to previous cropping influences. Lack of homogeneity can be due to inherent soil differences and previous cropping and cultivation. For valid trials, differences due to prior cropping have to be greatly reduced or eliminated if possible. To achieve this, it is essential to have one common crop, and preferably two crops, between years when field trials are conducted. What is normally observed after any field trial, especially under dryland conditions, is that alleyways between plots and growth differences within plots express themselves in differences in residual soil moisture, organic matter, and nutrient availability in the following year. Carryover of soil-borne diseases is less apparent.

In order or eliminate such carryover effects from experimentation, it is necessary to subject the area to homogenous cover cropping. The intensity of cover cropping depends on the demands by scientific staff for land for experimentation. An ideal cover crop requires that the following management treatments are all uniform and 
consistent: cultivation depth and type; planting rate, method and depth; fertilization, weed control, plant protection and harvesting. Another strategy to reduce residual variability in experimental plots is to reduce or minimize border effects during the experimental period. This is best achieved with solid planting with no extra space on either side of the experimental plots. This is more difficult for legumes because of their open pollination.

While a research station has to follow a more complex rotation than a farm, such rotations have to be cost-effective. The primary focus is not profitability but providing for homogenous land to conduct research. At ICARDA the focus is on essentially two crop groupings, cereals and legumes, the common system of cover-cropping involves cereals/legumes, i.e., where cereals are in experimentation, the following year is in uniform legumes, and vice versa; for instance, in trials involving barley, the cover crop is lentil or chickpea in a bi-annual rotation. Where soil-borne cereal diseases are a problem, wider rotations as a cover crop are advisable, i.e., 3 or 4-course rotations. The extra crop years could include crops currently used at the station, e.g., cumin (Cuminum cyminum), coriander (Coriandrum sativum), safflower, vetch, or a less common cereal such as oats (Avena sativa).

A serious limitation in on-station experimentation is the occurrence of parasitic weeds that are common to the Mediterranean region. At Tel Hadya, various Orobanche species, mostly $O$. crenata and $O$. aegyptiaca, as well as Cuscuta species, exist and limit the suitability of large areas for susceptible crops, mainly legumes, but also other dicotylidae such as the newly introduced spice crops. This crop parasitism has implications on the management of the research site. Legume work is limited and an ideal rotation does include less than $50 \%$ legumes. For legume research areas, as well as for a general hygiene, a six-course rotation with only 2 years of legumes, best rotated between lentils and chickpeas, or lentils and faba beans, is recommended. Based on these considerations, the Station is restricted to no more than 200 to 250 ha of small plot work research per year; using a larger area in any one year creates more limitations the following year.

\subsubsection{Crop Management}

Cropping intensity is largely dictated by seasonal rainfall, with most of the Station under rainfed crops from November to May/June. Some supplemental irrigation is used during the season, especially in periods of drought. Cropping during the dry hot summer period is rare. As weeds compete with the crop for moisture, nutrients, and light, their control is essential for achieving economic yields on-farm, and of major importance in field experimentation. Therefore it is of paramount importance for the station to have effective in-crop weed management control options, both for the previous crops and also the current season crops. This is achieved by removal of volunteers by either tillage; prior to crop establishment or in some instances in-furrow cultivation post cropping or by use of knockdown, pre- or post emergence herbicides applications.

As the parasitic weed Orobanche is endemic in the WANA region, selective herbicides help to reduce its intensity, extending the period of cover-cropping with cereals or another non-legume crop can help reduce infection. Despite the general need to control weeds, one must bear in mind that in some areas of the North Africa region, such as Morocco, farmers regard weeds as a forage for animals during the cereal-growing season when other fodder is scarce. In such cases, weeds are pulled by hand and fed to livestock.

\subsubsection{Bio-Security}

As with operators of experiment stations in most places ICARDA is mindful of issues related to bio-security, which refers to a set of measures or protocols designed to protect the Station from entry and spread of intruders, including unwanted animals, pests, diseases, and weeds. However, few stations can prevent wind-borne diseases, spores, and seeds, or movement of some wildlife and feral animals. Some of the routine procedures for maintaining bio-security include: accessing clean materials from sources known to be free of diseases, weeds and pests; training staff on aspects of bio-security; providing wash-down and quarantine facilities; keeping roads and open areas weed-free; restricting visitors mainly to the central administration area and Station's main roads.

\subsubsection{Support Services}

In addition to providing field areas for experimentation, the Station provides an extensive area of environmentally controlled greenhouses (plastic houses and glasshouses), depending of the particular scientific needs, and a seed health facility for fumigation and disease control. The Seed Processing plant has a unique role at the Station in view of the absence of such facilities in the region and the general weakness of the private seed sector. The Center lagoon area on the land for disposal of laboratory wastes. In keeping with its mandate to collaborate with the national agricultural research programs, especially those of the host-country Syria, the Center provides a section of the station for crop experimentation, both irrigated and rainfed, by staff from the 
Syrian Ministry of Agriculture; this close association reflects an overall synergy of the Center with the national agricultural research systems (NARS) of its mandate region.. Though not directly related to station management, given the large number of employees at the Center, especially local support and seasonal staff, the Station maintains a Clinic with a qualified physician for dealing with routine health care and an ambulance for emergencies.

\subsubsection{Additional Features}

The Station is unique in that is has features not usually found in agricultural experiment stations, either in the Middle East region or elsewhere.

\section{a. Arboretum}

As many tree species of economic importance are native to the region, with some current or potential importance, the Center established an Arboretum in the past decade in which all of the common tree crops in the Middle East are grown and maintained for demonstration. The purpose of the demonstration area, prominently sited on the hillside opposite the main Administration and Research Complex adjacent to the main avenue in the Center, was to make scientists and visitors aware of the complimentary role such trees can play in the farming system in the region and that they can contribute to household income and nutritional diversity. The array of species reflects the rich biodiversity in the Mediterranean region.

The trees in the Arboretum include include many varieties of olive (Olea europea), pomegranate (Punica granitum), pistachio (Pistacia vera), almond (Amygdalius communis), carob (Ceratonia siliqua), and quince (Cydonia oblonga). This permanent site is designed to show the "sustainability" of such species in the landscape and to contribute to cultural and artistic values of local communities as some of these species are have a special place in the folklore of the region

\section{b. Pasturetum}

The Center also maintains a Pasturetum and medical plant garden adjacent to the Sheep Unit. This 5-ha site, established in 1998, has 29 species of rangeland shrubs that are used as forage for sheep and goats. In view of the large areas of rangelands in the WANA region, efforts were made over the years to include all the major forage species available. The main species in the collection include wormwood (Artemesia herba-alba), saltbush (Atriplex spp), black saxaul (Haloxylon aphyllum), forage kochia (Bassia prostrate), shrubby Russian thistle (Salsola vermiculata), bladder senna (Colutea Istria), shrubby medick (Medicago arborea), carob (Ceratonia siliqua), Mount Altas pistache (Pistacia atlantica) acacia ((Acacia spp), spineless cactus (Opuntia ficus-indica), cocksfoot grass (Dactylis glomerata), and Panic Du Sahara (Panicum turgidum).

By 2003, the Pasturetum had 100 biotypes of forage species. Particular emphasis has been given to saltbush, as it is drought-tolerant, with demonstration rows $(20 \mathrm{~m}$ by $3 \mathrm{~m})$ of the main varieties of saltbush on display. Despite its value as a "survival" forage, saltbush requires adequate supplies of drinking water for the animals. The Center also features a prominent site in which several of the common forage shrubs, particularly saltbush, are used for water-harvesting demonstration.

Medicinal plants in the Pasturetum include common caper (Capparis spinosa), fernleaf yarrow (Achillea filipendulina), wild marjoram ((Origanum vulgare), and Tanner's sumach (Rhus coreiaria). Ornamental species grown for aesthetic purposes include oleander (Nerium oleander), hollylock (Alcea rosea), common myrtle (Myrtus communis), Jerusalem thorn (Parkinsonia aculeate), Spanish broom (Spartium junceum). The main aromatic plants in the collection were Greek sage (Salvia fructicosa), fernleaf lavender (Lavandula multifida), felty germander (Teucrium polium), as well as wormwood. The entire collection of plant species was added to significantly in 2009 by materials from Central Asia, Australia and North Africa.

\section{c. Archaeological Sites}

With the Middle East being the main area of the world where settled agriculture began and the center-of-origin of cereals, pulses, and nut crops (Harlan, 1992), the landscape is dotted with habitation sites, particularly man-made elevated mounds or "tells" (Ryan et al., 2009b). As the ICARDA station at Tel Hadya features a natural prominent tell or hill, from which it derives its name, numerous archaeological features are found on the hill itself and in its immediate environs. Investigations involving the Aleppo Museum and outside interests (Hammade and Koike, 1991) identified three distinct historical periods from the artifacts (pottery, coins, glass beads, etc) found at the tell site; Byzantine (5-6th Century AD), Ayyubid and Manluk-Medieval (12-14th Century), and end of the Ottoman period (19th to early 20th Century). The hill features several cisterns for water collection and storage. 
Cutting across the main experimental fields to the north of the site is a Roman aquaduct, or underground channel; this can be seen in some exposed sections $(200 \mathrm{~m})$ and is about 2-3 $\mathrm{m}$ deep and cut into the underlying limestone; it about $0.62-0.65 \mathrm{~m}$ wide and $1.45 \mathrm{~m}$ high. The aquaduct was used to convey water from a source about $50 \mathrm{~km}$ to the west near the modern-day Turkish city of Reyhanli to the area around present-day Tel Hadya.

While such archaeological features are primarily of interests to archaeologists, they do serve to make the current generation of scientists at the Center aware of the antiquity of agriculture in the region and that our ancestors used their "indigenous knowledge" to grapple with problems of water collection and conveyance, issues that we still contend with today.

\section{d. Bio-Pest Control}

As in all agricultural production systems, control of pests is a main concern. While weeds are controlled conventionally as indicated above, a unique approach has been adopted to reduce the ravages to growing and harvested crops by rodents, particularly voles and moles. While snakes serve as natural predators of such pests, birds are more effective control agents, particularly kestrels. In order to avoid the use of poison baits to control voles, efforts were made to promote populations of natural avian predators such as kestrels, kites, harriers, barn owls and little owls. Accordingly, nesting boxes were installed along the cliff face at the hill excavation. Perches were placed throughout the experimental fields for the birds of prey to eliminate voles from the plots. Currently, the Center is home to about 50 kestrels that provide a free pest control service.

\section{e. Uncropped Area}

An area of about 1 ha was set aside in the rangeland area and fenced off in 1989 to examine the ecological changes with time in terms of soil evolution and botanical composition. While no assessment has yet been made of the possible changes with time, the effect is necessarily long-term and may, in due course, yield valuable scientific information regarding Mediterranean dryland ecosystems. Similarly, an observation area is maintained by the Genetic Resources Unit on an area of deep soil in order to observe changes in native plant species composition.

\subsubsection{Other Issues}

An experimental station such as Tel Hadya has to facilitate applied research while maintaining relevance to the conditions of the region that it serves. The Center has to balance the need for using modern machinery while recognizing the conditions and limitations of target farmers who visit the Center on field days. The Center's small-scale farmer clients have to be able to realistically relate to the type and scale of new technology before they can embrace it.

Other issues in the management of the Center, as a primarily rainfed cropping institute, often pose a philosophical conflict. In the case of dryland crops that may perish during periods of extended drought, is it permissible to use irrigation to save the experimental crop? A similar dilemma is faced with the expansion of irrigation from groundwater when evidence exists of a constant decline in groundwater levels due to overexploitation. Regardless of whether the Center embraces irrigated agriculture, the station serves an important function of accurately monitoring groundwater levels, and thus serving as a barometer of irrigated agriculture in the surrounding area.

Notwithstanding the need to reflect conditions applicable to farmers of the region, the Station has a unique role in furthering new and potentially adaptable technologies. A major example is the use of conservation or minimum tillage. While the practice is common on most farms in many countries such as USA, Brazil, and Australia, it has not yet reached any significant level of farmer adoption in the Middle East region despite research on conservation tillage and related issues in Morocco for the past few decades (Mrabet, 1997). Currently, as a result of an Australian-funded project, major efforts are underway at the Station to demonstrate to local and regional farmers the benefits and sustainability of conservation tillage and crop residue management.

A key function of the experiment station at Tel Hadya involves training of staff from the national programs at all levels and across various disciplines. Such courses are of varying duration and involve technical staff from the Center's scientific programs. In addition to such courses, the Experimental Station Operation Management course, designed for managers of experimental stations in the WANA region, involves organization of the research facilities, fields, and equipment to conduct experiments and offers training to staff in field experimentation implementation and management.

A major consideration in the management of a main research such as Tel Hadya, which serves the research needs of a large scientific staff, is adequate capital investment. With a trend towards diminished global investment in agriculture, the impact has been felt with the international agricultural research centers. In such centers, funding 
for the operation of the experimentation and its facilities is particularly vulnerable. The situation is exacerbated by the trend in the past few decades of funding for restricted projects and a declining proportion of unrestricted funds. Funding for capital investment is difficult and not appealing to donors.

\section{Conclusions}

ICARDA's experimentation at Tel Hadya has served a vital role in the development of the dryland applied agricultural research since its inception and has had a catalytic role in transferring such technologies to the farming community in northern Syria and the countries of the region. Much of the success of the Center in influencing the wider Middle East region is based on its training program (Ryan et al., 2012b). Despite a trend towards more "upstream' research, such as in the area of biotechnology, the applied agronomic research backstopped by the Station is likely to maintain its relevance for the foreseeable future. We content that without the applied agricultural research program conducted at the station, there would be little impact of the Center on the agricultural sector of the region. Given the likelihood of increasing aridity due to climate change, the Station is of crucial importance is assessing the climatic adaptation of crop varieties. In addition, in view of its unique features such as the arboretum, pasturetum, and archaeological sites, the Station has a wider educational and scientific appeal beyond the concerns of production agriculture.

\section{Acknowledgement}

We thank Mr Amin Al-Khatib Salkini for information on the Arboretum and the Pasturetum.

\section{Refernces}

Abdel Monem, M., Lindsay, W. L., Sommer, R., \& Ryan, J. (2010). Loss of nitrogen from urea applied to rainfed wheat in varying rainfall wheat in varying rainfall zones in northern Syria. Nutrient Cycling in Agroecosystems, 86, 357-366. http://dx.doi.org/10.1007/s10705-009-9297-0

Abi-Ghanem, R., Carpenter-Boggs, L., Koenig, R., Pankuk, C., Pan, W., \& Parker, R. (2009). Extension education for dryland cropping systems in Iraq. Journal of Natural Resources \& Life Science Education, 38, 133-139.

Brams, E. (1980). Delivery from hunger: a model for transfer of agricultural technology to small-scale farmers? Journal of Agronomic Education, 9, 57-61.

Chaudhary, M. A., \& Ryan, J. (1984). Constraints to effective agricultural extension in the Middle East. Journal of Agronomic Education, 13, 89-93.

Cooper, P. J. M., Gregory, P. J, Tully, D., \& Harris, H. C. (1987). Improving water-use efficiency of annual crops in the rainfed farming systems of West Asia and North Africa. Experimental Agriculture, 23, 113-158. http://dx.doi.org/10.1017/S001447970001694X

Deane, C., Ejela, G., Rabbinge, R., \& Sayer, J. (2010). Science for development: mobilizing global partnership. Crop Science, 50, 1-7. http://dx.doi.org/10.2135/cropsci2010.12.0001

Godfray, C., Beddington, J. R., Crute, I. R., Haddad, L., Lawrence, D., Muir, J. F., Pretty, J., Robinson, S., Thomas, S. M., \& Toulmin, C. (2010). Food security: the challenge of feeding 9 billion people. Science, 327, 812-818. http://dx.doi.org/10.1126/science.1185383

Hammade, H., \& Koike, Y. (1991). Preliminary report about archaeological project at Tel Hadya. Unpublished report, The International Center for Agricultural Research in the Dry Areas, Aleppo, Syria.

Harlan, J. R. (1992). Crops and man, (2nd ed.). Am. Soc., Agron., Crop Sci. Soc., Am., Madison, WI, USA.

Illiawi, M. (1985). Soil map of Syria and Lebanon. Arab Center for the Studies of Arid Zones and Dry Lands (ACSAD), Damascus, Syria.

Jenkinson, D. S. (1991). The Rothamsted long-term experiments: are they still of use? Agronomy Journal, 83, 2-10. http://dx.doi.org/10.2134/agronj1991.00021962008300010008x

Jones, M. (2000). Anticipatory long-term research for sustainable productivity. Experimental Agriculture, 36, 137-150. http://dx.doi.org/10.1017/S0014479700002040

Karlen, E. L., Varvel, G. E., Bullock, D. G., \& Cruse, R. H. (1994). Crop rotations for the $20^{\text {th }}$ century. Advances in Agronomy, 53, 1-45. http://dx.doi.org/10.1016/S0065-2113(08)60611-2

Kassam, A. (1981). Climate, soil and land resources of North Africa and West Asia. Plant and Soil, 58, 1-29. http://dx.doi.org/10.1007/BF02180047

Keatinge, J. D. H., \& Sommel, K. (1993). Guidelines for improved agronomic management and economic 
evaluation of crop rotation trials in Mediterranean environment. Experimental Agriculture, 29, 437-447. http://dx.doi.org/10.1017/S0014479700021153

Khuri, N., Shideed, K., \& Kherallah, M. (2011). Food security: perspectives from the Arab word. Food Security 3 (Supplement 1), S1-S6. http://dx.doi.org/10.1007/s12571-010-0101-4

Kirschenmann, F. (2007). Potential for a new generation of biodiversity in agroecosystems of the future. Agronomy Journal, 99, 373-376. http://dx.doi.org/10.2134/agronj2006.0104

Miller, F. (2008). After 10,000 years of agriculture, whither agronomy? Agronomy Journal, 100, 22-34. http://dx.doi.org/10.2134/agrojnl2007.0013

Mrabet, R. (1997). Crop residue management and tillage systems for water conservation in a semi-arid area of Morocco. Ph.D. Diss., Colorado State University, Fort Collins, Colorado, CO., USA.

Nour, M. A. (2002). ICARDA 25: A promise of hope. International Center for Agricultural Research in the Dry Areas, Aleppo, Syria.

Osman, A. E., Cocks, P. C., Russi, L., \& Pagnotta, M. A. (1991). Response of Mediterranean grassland to phosphate and stocking rates: livestock production. Journal of Agricultural Science (Cambridge), 123, 319-326. http://dx.doi.org/10.1017/S0021859600070313

Pala, M., Matar, A., \& Mazid, A. (1996). Assessment of the effects of environmental factors on the response of wheat to fertilizer in on-farm trials in a Mediterranean-type environment. Experimental Agriculture, 32, 339-349. http://dx.doi.org/10.1017/S0014479700026272

Pala, M., Ryan, J. Diekmann, J., \& Singh, M. (2008). Barley and vetch yields from dryland rotations with varying tillage and residue management under Mediterranean conditions. Experimental Agriculture, 45, 205-216.

Rhoades, R. E. (1984). Understanding small-scale farmers in developing countries: sociocultural on agronomic farm trials. Journal of Agronomic Education, 13, 64-68.

Ryan, J., Abdel Monem, M., \& El Gharous, M. (1990). Soil fertility assessment at agricultural experiment stations in Chaouia, Abda, and Doukkala. Al-Awamia, 72, 1-47.

Ryan, J., Masri, S. Garabet, S., Diekmann, J., \& Habib, H. (1997). Soils of ICARDA's agricultural experiment stations and sites: climate classification, physical and chemical properties, and land use. Technical Bulletin, International Center for Agricultural Research in the Dry Areas, Aleppo, Syria.

Ryan, J., De Pauw, E., Gomez, H., \& Mrabet, R. (2006). Drylands of the Mediterranean zone: Biophysical resources and cropping systems. In G.A. Peterson, P.W. Unger, \&W.A. Payne (Ed) Dryland agriculture (pp. 577-624). Agronomy Monograph No. 23, Am. Soc. Agron., Madison, WI. USA.

Ryan, J., El-Mourid, M., Shroyer, J. P., \& El-Gharous, M. (2007). The Dryland Applied Research Project in Morocco: A perspective 12 years after completion. Journal of Natural Resources \& Life Sciences Education, $36,120-129$

Ryan, J., Singh, M., \& Pala, M._(2008a). Long-term cereal-based rotation trials in the Mediterranean region: implications for cropping sustainability. Advances in Agronomy, 97, 273-319. http://dx.doi.org/10.1016/S0065-2113(07)00007-7

Ryan, J., Ibrikci, H., Singh, M., Rashid, A., Matar, A., Masri, S., \& Pala, M. (2008b). Response to residual and currently applied phosphorus in three Syrian agroecosystems. European Journal of Agronomy, 28, 126-137. http://dx.doi.org/10.1016/j.eja.2007.06.001

Ryan, K. M., Neill, A., Ibrikci, H., \& Sommer, R. (2009a). Nitrogen in irrigation and rainfed cropping systems of the Mediterranean. Advances in Agronomy, 97, 276-324.

Ryan, J., S. Kapur, S., \& Akca, E. (2009b). Application of soil analyses as markers to characterize Middle Eastern Chalcolithic-Late Bronze Age mounds. TUBA-AR (Turkish Academy of Sciences J. Archaeology, Ankara, Turkey), 12, 65-76.

Ryan, J., Singh, M., Pala, M., Makboul, R., Masri, S., Harris, H. C., \& Sommer, R. (2010). Crop sequences, nitrogen fertilizer, and grazing intensity in relation to wheat yields in rainfed systems. Journal of Agricultural Science (Cambridge), 148, 205-216. http://dx.doi.org/10.1017/S0021859609990566

Ryan, J., Singh, M., Masri, S., \& Ibrikci, H. (2012a). Spatial variation in soil organic matter, available phosphorus and potassium under semi-arid conditions: research station management implications. 
Communications in Soil Science \& Plant Analysis, 43 (in press).

Ryan, J., Ibrahim, H., Dakermanji, A., \& Niane, A. A. (2012b). Training and capacity building; an essential strategy for development at an international research center. Sustainable Agricultural Research (in press).

Sacks, J. (2004). Sustainable developments. Science, 304, 649. http://dx.doi.org/10.1126/science.304.5671.649

Soil Survey Staff. (1975). Soil taxonomy: a basic system of soil classification for making and interpreting soil surveys. United States Department of Agriculture Handbook No. 436. Washington, D.C., USA.

World Development Report. (2008). Agriculture fro development. World Bank, Washington, DC, USA.

World Resources Institute. (2000). The weight of nations: Material outflow from industrial economies. World Resources Institute, Washington, DC, USA. 